\title{
DEGRADATIONOF LAUNDRYWASTEWATER BY ELECTROLYSIS METHOD USING CARBON ELECTRODE
}

\author{
${ }^{\mathrm{a}}$ Teguh Imam Handoko, ${ }^{\mathrm{a}}$ Riyanto dan ${ }^{\mathrm{a}}$ Tatang Shabur Julianto
}

\author{
Progam Studi Ilmu Kimia, FMIPA, Universitas Islam Indonesia \\ Jl. Kaliurang KM 14,5Sleman Yogyakarta 55584 \\ Email: Teguhhandoko1992@yahoo.co.id
}

\begin{abstract}
ABSTRAK
Telah dilakukan penelitian tentang degradasi limbah laundri dengan metode elektrolisis menggunakan elektroda karbon. Limbah laundri sangat berbahaya bagi lingkunan.

Limbah laundri yang sebelumnya sering dibuang ke badan air dan mencemari lingkungan dimasukkan ke dalam gelas beker yang sudah diberikan pengaduk magnetik. Elektroda karbon kemudian dipasang sedemikian rupa sehingga kedua elektroda saling berdekatan. Kemudian elektroda dihubungkan dengan sumber arus dirrect current. Dalam penelitian ini dilakukan variasi tegangan dan waktu yaitu pada tegangan5-20 volt dan 1-5 jam. Katoda dihubungkan dengan kutub positif, sedangkan anoda dihubungkan dengan kutub negatif. Pada katoda dan anoda luas yang tercelup ke dalam larutan sedalam $4 \mathrm{~cm}$ dengan luas permukaan $9,4 \mathrm{~cm}^{2}$.

Hasil penelitian menunjukkan bahwa arus dan waktu sangat berpengaruh terhadap presentase degradasi limbah laundri. Presentase degradasi limbah laundri yang didapatkan dengan hasil baik yaitu sebesar 50,98 \% pada saat elektrolisis dengan potensi 20 volt dengan waktu elektrolisis 5 jam.
\end{abstract}

Kata kunci: anoda, katoda, elektrolisis, limbah laundri

\begin{abstract}
Degradation of laundry wastewater by electrolysis method using carbon electrode has been done. The laundry watewater is very dangerous if it has discarded to environment. Research has been done to decreased the polutan of laundry wastewater.

Waste water laundrywhich previously often disposed into water and pollute the environment put into a glass beaker that has been given a magnetic stirrer. Then the carbon electrodes and placed so that both electrodes are close together. Then the electrodes is connected to the current source dirrect current. In this research, the determination of the voltage and time at 5-20 volts and the time for 1-5 hours.Cathode connected to the negative pole, while the anode is connected to the positive pole. At the cathode and anode are immersed into a solution of a broad depth of $4 \mathrm{~cm}$ with a surface area of $9.4 \mathrm{~cm}^{2}$.

The results showed that the current and future influence on the percentage of degradation of waste facilities. Laundry waste degradation percentage obtained with good results in the amount of 50,98 \% during electrolysis with potential 20 volt and 5 hours.
\end{abstract}

Keyword: anode, cathode, electrolysis, laundry wastewater. 


\section{PENDAHULUAN}

Limbah laundri yaitu limbah hasil pembuangan dan sisa dari jasa pencucian laundri, dimana pada limbah laundri banyak terdapat bahan-bahan yang berbahaya. Selain itu limbah laundri juga sangat berbahaya saat tercampur dengan makanan ataaupun minuman, karena zat-zat yang berbahaya dapat merusak organ didalam tubuh.Kandungan yang terdapat dalam limbah laundri diantaranya yaitu surfaktan dan zat-zat yang banyak mengandung senyawa organik (Smulders, 2002).

Karena sifatnya yang kompleks, air limbah deterjen/laundri sangat sukar untuk diolah.Metoda yang dapat diterapkan untuk mereduksi surfaktan mencakup proses-proses kimia dan oksidasi elektrokimia, teknologi membran, presipitasi secara kimia,degradasi fotokatalitik, adsorbsi dan berbagai metoda biologis yang tidak begitu efektif karena proses yang berlangsung lambat. Untuk melindungi lingkungan terhadap pengaruh air limbah khususnya deterjen/laundri maka perlu dicari metode pengolahan yang efisien (Aygun dan Yilmas, 2010).

Air merupakan komponen vital dalam operasi suatu industri laundri (binatu). Kebutuhan air untuk industri laundri rata-rata $15 \mathrm{~L}$ untuk memroses $1 \mathrm{~kg}$ pakaian dan menghasilkan $400 \mathrm{~m}^{3}$ limbah cair per hari (Ciabattiet al, 2010).

Kebanyakan sistem yang digunakan pada proses pengolahan air limbah industri laundri merupakan metoda konvensional seperti presipitasi/koagulasi dan dan flokulasi, sedimentasi dan filtrasi atau kombinasi dari proses-proses tersebut.

Koagulasi dan flokulasi biasanya ditambahkan untuk membentuk formasi dari partikel besar yang teraglomerasi. Sistem ini tidak efektif untuk menghilangkan warna dari efluent (sisa deterjen) dari proses laundri.

Adsorbsi menggunakan karbon aktif granular setelah proses flokulasi dapat meningkatkan proses pengolahan karena luas permukaan karbon aktif yang besar dapat menyerap komponen-komponen yang ada dalam air limbah. Namun 
demikian untuk menghilangkan warna sangat tergantung dari jenis zat warna yang digunakan (Turk et al, 2005).

Elektrolisis adalah salah satu bidang elektrokimia yang mengkaji perpindahan elektron dipermukaan elektroda. Teknik ini ramah lingkungan sehingga dikenal sebagai salah satu teknik teknologi hijau masa depan (Siu dan Yudin, 2002).

Teknik elektrokimia merupakan teknologi kimia yang paling inovatif. Teknik elektrolisis merupakan teknik dengan biaya yang rendah dan menghasilkan bahan dengan kemurnian tinggi. Teknik elektrokimia adalah teknik yang menggunakan elektroda sebagai katalis heterogen (Riyanto, 2013).

Elektrolisis adalah suatu proses dimana reaksi kimia terjadi pada elektroda tercelup dalam larutan elektrolit ketika tegangan diterapkan terhadap elektroda tersebut. Elektroda yang mengalami proses reduksi disebut katoda.

Bagian terpenting dalam teknik elektrolisis adalah elektroda. Elektroda yang baik adalah harus memiliki sifat kestabilan, konduktivitas, dan elektrokatalis yang baik. Anoda yang digunakan untuk oksidasi harus memiliki sifat kestabilan dalam larutan limbah yang dielektrolisis, mudah dihasilkan serta murah harganya (Riyanto, 2013).

Karbon mengisi tempat khusus diantara unsur-unsur dalam keragaman dan kekompleksan senyawa yang dapat dibentuknya. Hal itu dapat disebabkan oleh ikatan kuat antara C-C, yang memungkinkan atom-atom C berikatan satu sama lain membentuk rantai panjang, cincin, atau kombinasi cincin dan rantai. Selanjutnya, konfigurasi elektron karbon dalam keadaan dasar $\left(1 s^{2} 2 s^{2} 2 p^{2}\right) \quad$ mudah terhibridisasi membentuk perangkat orbital $\mathrm{sp}^{3}$, atau $\mathrm{sp}^{2}+\mathrm{p}$, atau $\mathrm{sp}+\mathrm{p}^{2}$. Berarti struktur rantai atau cincin karbon dapat digandakan seperti halnya ikatan-ikatan tunggal antara atomatom C. Bentuk fisik dari karbon terdiri dari dua macam bahan karbon, yakni intan dan gravit, sebagai contoh padatan kovalen jaringan (Critenden, 1998). 


\section{METODE PENELITIAN}

Peralatan yang digunakan berupa seperangkat alat elektrolisis, $\mathrm{pH}$ meter, dan perlengkapan gelas serta spektrofotometer UV-Vis. Sedangkan bahan-bahan yang digunakan yaitu berupa sampel limbah laundri, kemudian akuades, dan $\mathrm{Na}_{2} \mathrm{SO}_{4}$ yang digunakan sebagai elektrolit. Kemudian dalam pengukuran COD dalam limbah bahan-bahan yang digunakan yaitu berupa larutan standar KHP, $\mathrm{Hg}_{2} \mathrm{SO}_{4}, \mathrm{Ag}_{2} \mathrm{SO}_{4}$, serta $\mathrm{K}_{2} \mathrm{Cr}_{2} \mathrm{O}_{7}$.

Elektrolit yang digunakan dalam proses elektrolisis yaitu $\mathrm{Na}_{2} \mathrm{SO}_{4}$ sebanyak 0,25 gram yang kemudian ditambahkan kedalam sampel limbah laundri yang sudah disiapkan dalam gelas beker dengan volume limbah laundri $100 \mathrm{ml}$.

Metode yang digunakan yaitu proses elektrolisis kemudian dilakukan pengukuran dengan menggunakan spektofotometer UVVis yang kemudian diukur absorbansi dari sampel dan dari hasil elektrolisis untuk menentukan penurunan persentasi degradasi limbah laundri dengan perhitungan menggunakan rumus:
Ob degradasi $=\frac{\text { absorbansisampel }}{\text { absorbansisampel hasil }} x 100 \%$

Kemudian setelah diketahui hasil dari penurunan dari persentasi degradasi limbah laundri berikutnya dilakukan pengukuran COD untuk menentukan hasil dari elektrolisis tersebut berpengaruh terhadap penurunan kadar COD.

\section{HASIL DAN PEMBAHASAN}

\section{Elektroda karbon yang digunakan untuk elektrolisis.}

Pada penelitian ini elektroda yang digunakan yaitu berupa elektroda yang terbentuk dari grafit. Dalam penggunaannya lebih sering digunakan sebagai alat tulis dalam kehidupan sehari-hari. Elektroda ini mudah didapatkan dari berbagai toko alat tulis dan sangat terjangkau yang menjadikan pada penelitian ini digunakan elektroda tersebut sebagai elektroda dalam proses elektrolisis. 


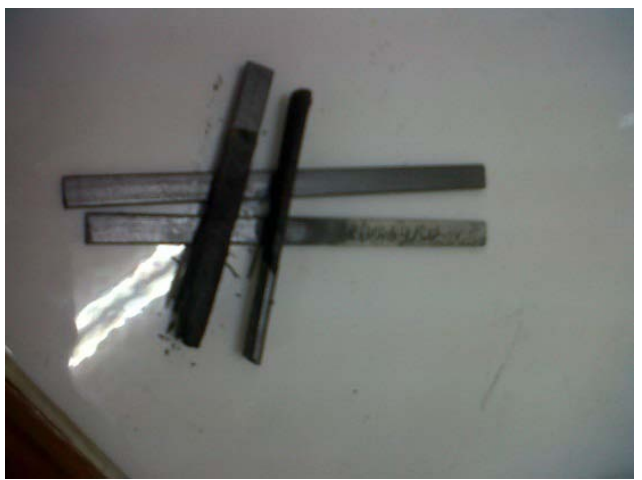

Gambar 1. Elektroda yang digunakan pada elektrolisis

Selain dikarenakan mudah didapatkan dan sangat terjangkau, penggunaan elektroda ini juga dikarenakan ketahanannya selama proses elektrolisis. Elektroda grafit ini mampu mengalirkan arus listrik dengan sangat baik yang mengakibatkan proses reaksi yang terjadi dalam sel elektrolisis berlangsung dengan cepat.

\section{Hasil elektrolisis limbah laundri menggunakan tegangan 5 volt, 10 volt, 15 volt, dan 20 volt.}

Hasil analisis sampel limbah laundri dengan menggunakan spektrofotometri UV-Vis didapatkan spektrum seperti pada Gambar 2..

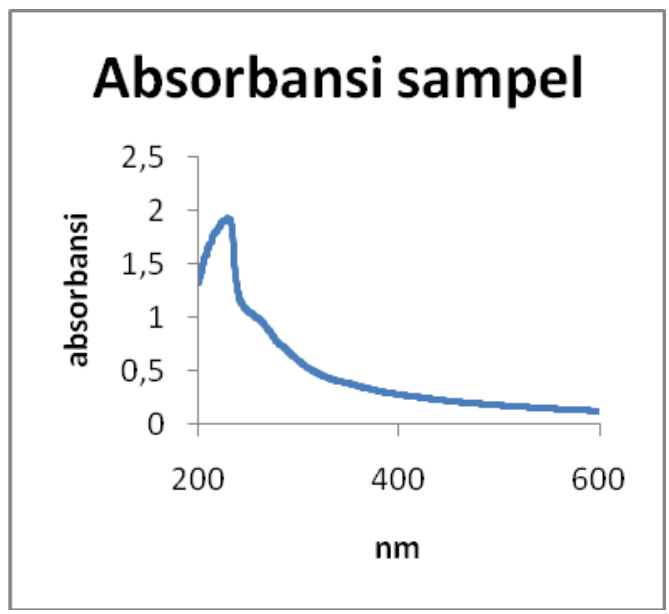

Gambar 2. Hasil spektrum sampel limbah laundri menggunakan UV-Vis

Gambar 2 adalah hasil spektrofotometri dengan menggunakan UV-Vis pada sampel limbah laundri. Pada spektrum tersebut terdapat puncak pada 236 nm yang kemungkinan adalah Linear Alkil Sulfonat yang merupakan kadar-kadar senyawa limbah dalam sampel ini. Dan pada sampel ini dilakukan berbagai elektrolisis dengan tegangan dan waktu yang berbeda untuk mendapatkan hasil elektrolisis limbah laundri dengan sempurna.

Pada analisis sampel tersebut puncak pertama terdapat pada rentang 220-230 nm dimana pada rentang tersebut adalah senyawa LAS atau Linear Alkil Sulfonat yang 
merupakan salah satu bahan penyususn detergen dan salah satu dari senyawa benzene yang dapat merusak lingkungan. Pada sampel tersebut senyawa LAS terbaca oleh spektrofotometri UV-Vis, struktur dari senyawa Linear Alkil Sulfonat seperti ditunjukkan Gambar 3.

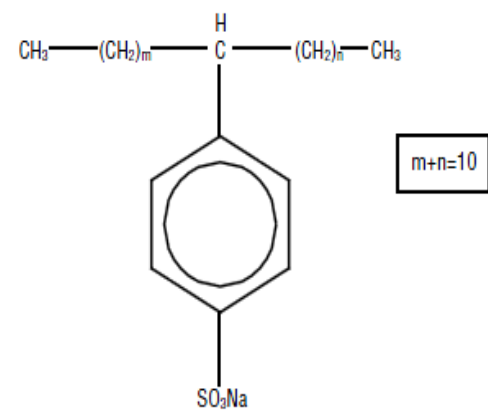

Gambar 3. Struktur LAS

$$
\text { Salah satu surfaktan }
$$
penyusun detergen yaitu LAS (Linear alkil benzene sulfonat). LAS bersifat anionik yang dapat merusak lingkungan, dalam perairan dapat menimbulkan masalah pencemaran karena pada konsentrasi tertentu di perairan cenderung sulit didegradasi sehingga menimbulkan masalah toksisitas terhadap biota perairan. LAS apabila berada ditanah dapat membunuh mikroba di tanah sehingga mengurangi kesuburan tanah serta dapat mengakibatkan iritasi terhadap kulit dan dapat menganggu kesehatan pada konsentrasi tertentu (Prianto, 2006).

Kemudian analisis berikutnya yaitu pada tegangan 5 volt, 10 volt, 15 volt, dan 20 volt dilakukan dengan variasi waktu dari 1 jam hingga 5 jam dengan hasil ditunjukkan oleh Gambar 4.
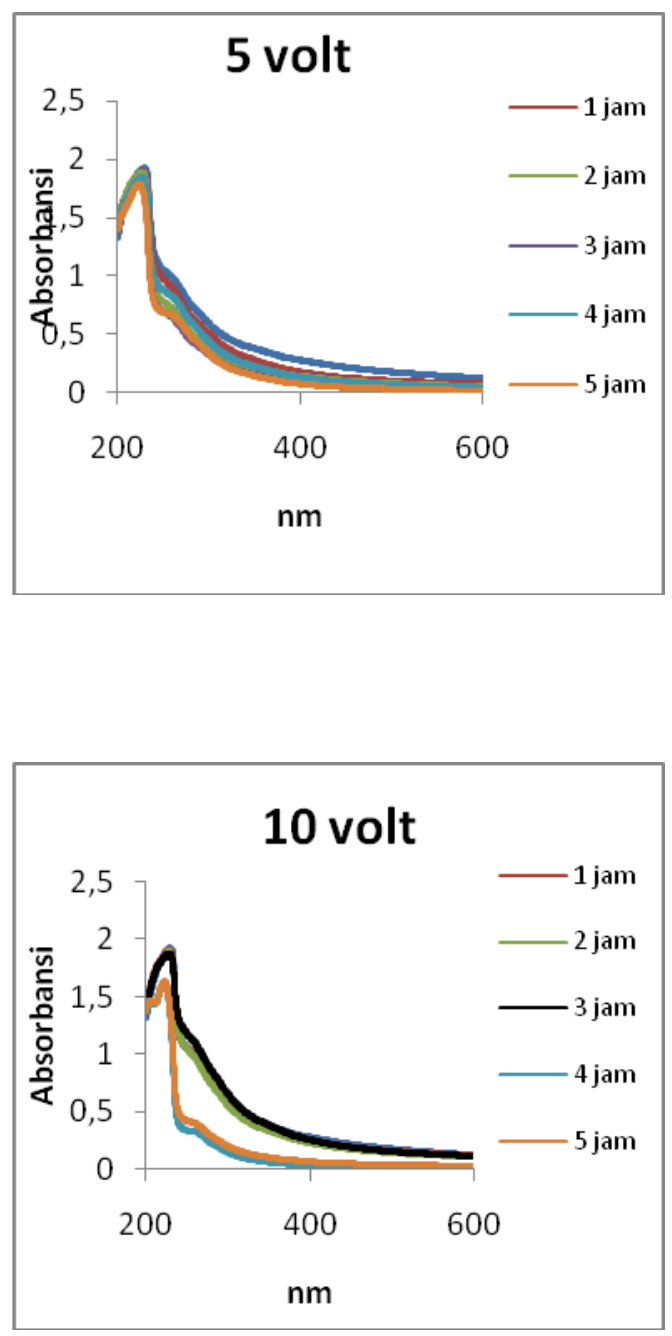

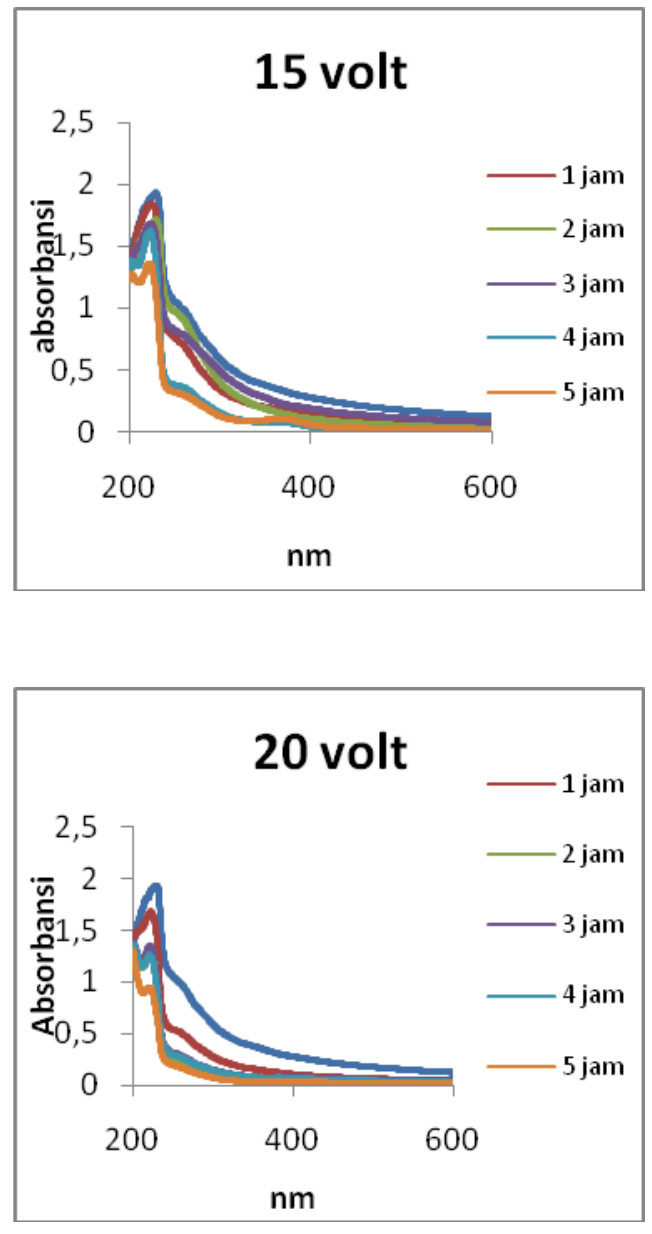

Gambar 4. Spektrum Uv-Vis dari tegangan 5 volt, 10 volt, 15 volt, dan 20 volt.

Gambar 4 merupakan hasil analisis dengan menggunakan spektrofotometri UV-Vis, dimana analisis dengan menggunakan tegangan 5 volt ini divariasikan dengan waktu yaitu 1 jam, 2 jam, 3 jam, 4 jam, da 5 jam. Pada spektrum dapat kita lihat penurunan puncak yang terbentuk dari limbah laundri tersebut, dimana semakin lama waktu yang digunakan untuk elektrolisis sangat berpengaruh terhadap puncak yang terbentuk dari penelitian ini.

Pada puncak tersebut didapatkan data bahwa pada elektrolisis dengan tegangan 5 volt didapatkan hasil bahwa elektrolisis dengan menggunakan waktu 5 jam memberikan pengaruh penurunan pada data analisis tersebut. Dari spektrum data penelitian diatas kemudian dapat dihitung presentase degradasi limbah laundri yang seperti ditunjukkan pada gambar 5 .

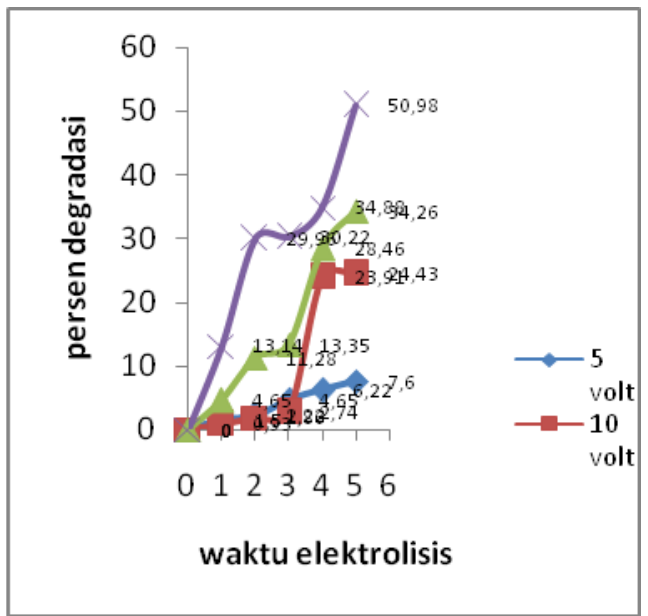

Gambar 5. Spektra persentase degradasi dengan menggunakan tegangan 5 volt, 10 volt, 15 volt, dan 20 volt.

Setelah sampel dielektrolisis beberapa jam dengan menggunakan 
tegangan 5 volt terjadi perubahan berupa timbulnya gelembung dan banyaknya buih yang terdapat disekitar elektroda. Hal ini menunjukkan bahwa elektroda sedang bereaksi dengan sampel yang sedang dianalisis. Pada elektrolisis tegangan 5 volt perubahan pada sampel cenderung tidak signifikan dalam arti proses degradasi berjalan sedikit lambat dan kurang cepat, meskipun untuk degradasi bisa dikatakan sedikit ada perubahan dibandingkan dengan warna sampel pada awalnya. Warna sampel kemudian setelah dielektrolisis beberapa lama berubah menjadi hitam pekat, disebabkan adanya karbon yang luruh dan ikut tercampur dari sampel. Kemudian hal itu menyebabkan sampel harus disaring terlenih dahulu untuk membuang sisa-sisa karbon yang ikut dalam larutan sampel tersebut.

Kemudian pada perlakuan elektrolisis menggunakan tegangan 10 volt ini perlakuannya sama dengan ketika menggunakan 5 volt. Hanya saja ketika elektrolisis tegangan yang diberikan dinaikkan menjadi 10 volt. Tegangan sangat berpengaruh terhadap hasil dari proses elektrolisis tersebut. Karena tegangan yang semakin besar akan menjadikan elektrolisis akan menjadi semakin baik.

Pada gambar 4 dapat dilihat bahwa penurunan secara signifikan ada pada 4 jam dan 5 jam dengan menggunakan elektrolisis tegangan 10 volt. Selain itu pada elektrolisis 10 volt ini didapatkan hasil penururnan puncak data spektrum dan penururnannya sedikit signifikan dibandingkan dengan menggunakan tegangan 5 volt.

Kemudian pada grafik persen degradasi tegangan 10 volt terlihat pada rentan waktu elektrolisis 1 jam, 2 jam, hingga 3 jam, persentase degradasi yang dihasilkan tidak begitu segnifikan, masih berada dalam rentan 0,9-2,8\%. Hasil yang kurang begitu maksimal untuk sebuah elektrolisis, kemudian penurunan yang sedikit signifikan terdapat pada rentan waktu 4 jam dan 5 jam yaitu berada pada rentan $24 \%$. Pengaruh waktu elektrolisis memang mempengaruhi penururnan hasil degradasi limbah laundri ini, semakin lama waktu elektrolisis yang 
dilakukan maka persentase Hasil dari spektrofotometri penurunan degradasi semakin besar.

Pada penelitian dan perlakuan berikutnya yaitu elektrolisis dengan menggunakan tegangan 15 volt. Diharapkan dengan menggunakan tegangan 15 volt ini akan didapatkan hasil penurunan kadar dan senyawa atau degradasi limbah laundri ini mencapai presentase degradasi yang signifikan. Pada elektrolisis tegangan 15 volt ini perlakuannya sama dengan proses elektrolisis yang lainnya, yaitu sampel $100 \mathrm{~mL}$ kemudian dimasukkan kedalam beker dan ditambahkan dengan elektrolit 0,25 gram $\mathrm{Na}_{2} \mathrm{SO}_{4}$ kedalam gelas beker yang sudah dilengkapi dengan pengaduk magnet dengan tujuan mendapatkan hasil yang baik apabila elektrolisisnya ditambahkan dengan pengadukan. Kemudian arus Dirrect Current dimasukkan kedalam sampel dan diatur tegangan yang diberikan yaitu 15 volt, dan rentan waktu yang dilakukan yaitu antara 1 jam hingga 5 jam. Kemudian dilakukan uji menggunakan spektofotometri UVVis untuk mengetahui perubahan selama proses elektrolisis. UV-Vis memberikan hasil penurunan yang sangat signifikan pada waktu 5 jam, dapat disimpulkan bahwa semakin lama waktu elektrolisis maka penurunuan senyawa atau kadar dalam limbah laundri ini sedikit mulai terlihat. Pada tegangan 15 volt ini karbon yang luruh juga semakin banyak dengan peluruhan yang bersifat rontokan kecil- kecil namun tidak larut ke dalam sampel limbah laundri tersebut, dalam hal ini karbon yang luruh tersebut tidak ikut bereaksi dengan sampel, hanya berupa luruhan dan seperti pengotor saja. Kedalam dalam pencelupan karbon yang digunakan dalam elektrolisis ini yaitu sedalam $4 \mathrm{~cm}$ memberikan tujuan agar karbon dapat mengalirkan arus dengan optimal, jadi kinerja dari elektrodanya akan semakin baik. Jarak antara kedua karbon juga dibuat sedemikian rupa setiap pengujian elektrolisis sama, yaitu hanya membutuhkan jarak 1-2 cm, agar reaksi perpindahan elektron yang terjadi didalam sampel akan berlangsung dengan baik. Selain itu jarak antar kedua elektroda apabila 
berjauhan akan memberikan hasil yang kurang maksimal.

Penurunan degradasi limbah laundri dengan tegangan 15 volt semakin lama waktu elektrolisisnya menunjukkan hasil persentase degradasi yang semakin naik, dapat kita lihat bahwa semakin lama persentase degradasinya semakin tinggi. Pada waktu 1 jam hanya didapatkan persentase degradasi dengan hasil 4,65\%, kemuidan pada waktu 2 jam terjadi penurunan degradasi sebanyak 11,28\%, dan pada 5 jam terjadi penurunan yang sangat signifikan yaitu sebesar 34,26\%. Hal ini menunjukkan bahwa waktu optimal yang baik untuk mendegradasi limbah laundri adalah 5 jam. Dari beberapa data didapatkan bahwa dengan elektrolisis 5 jam didapatkan hasil yang optimal. Apabila hanya dilakukan dalam rentan waktu 1 hingga 3 jam hasil yang didapatkan tidak akan optimal.

Penelitian degradasi limbah laundri yang terakhir yaitu elektrolisis dengan tegangan 20 volt. Dimana pada elektrolisis ini diharapkan persentase penurunan degradasi limbah laundri yang paling signifikan dibandingkan dengan tegangan 5 volt, 10 volt, dan 15 volt sebelumnya.

Pada tegangan 20 volt ini pada rentan waktu 4 dan 5 jam terjadi penururan puncak pertama dari sampel yang dianalisis menggunakan spektofotometri UVVis juga. Puncak yang awaalnya hampir mendekati absorbansi 2 kini toron menjadi 0,9. Kemudian pada elektrolisis dengan tegangan 20 volt ini baik dari 1 jam hingga 5 jam penurunan puncak pada spektrumnya sangat begitu terlihat.

Pada penurunan 1 jam sudah didapatkan penurunan sebanyak 13,14 \%. Dan penurunan paling signifikan yaitu pada 5 jam dengan tegangan 20 volt, dimana didapatkan degradasi limbah laundri hingga 50,98 \%. Dengan ini menunjukkan bahwa semakin lama waktu dan semakin tinggi tegangan akan memberikan hasil degradasi yang lebih baik.

\section{Analisis Penurunan Kadar} COD pada Limbah Laundri

Pada analisis ini yang diuji yaitu sampel awal sebelum dielektrolisis dan sampel yang sudah dielektrolisis dengan waktu dan tegangan paling 
optimal yaitu pada waktu 5 jam dan tegangan 20 volt.

Tabel 1. Absorbansi pengukuran COD

\begin{tabular}{|c|c|}
\hline Sampel & Absorbansi \\
\hline Std 1 (0 ppm) & 0 \\
\hline Std 2 (100 ppm) & 0,006 \\
\hline Std 3 (400 ppm) & 0,054 \\
\hline Std 4 (700 ppm) & 0,115 \\
\hline Std 5 (1000 ppm) & 0,137 \\
\hline $\begin{array}{c}\text { Sampel Hasil } \\
\text { Elektrolisis 20 volt } 5 \\
\text { jam. }\end{array}$ & 0,059 \\
\hline $\begin{array}{c}\text { Sampel Limbah } \\
\text { Awal }\end{array}$ & 0,0227 \\
\hline \multicolumn{2}{|c|}{} \\
\hline
\end{tabular}

Kemudian hasil dari pengukuran data absorbansi sampel dan standar tersebut dibentuk menjadi kurva kalibrasi untuk mengetahui koefisien korelasi dari pengukuran COD ini. Kemudian akan didapatkan persen penurunan degradasinya.

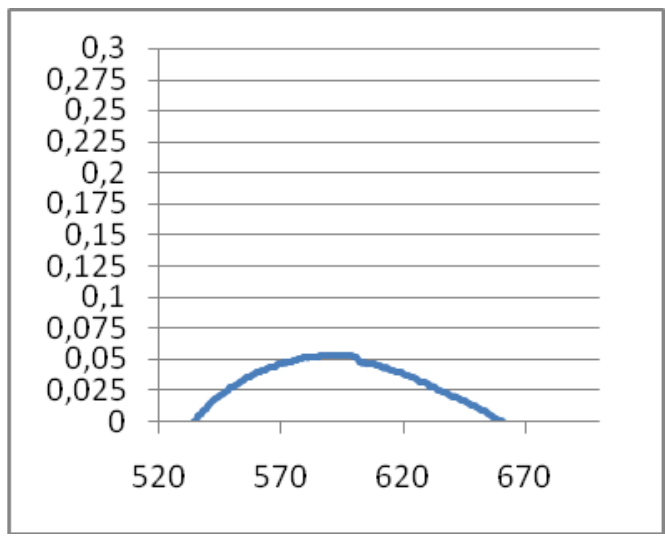

Gambar 6. Panjang gelombang maksimal pengukuran COD

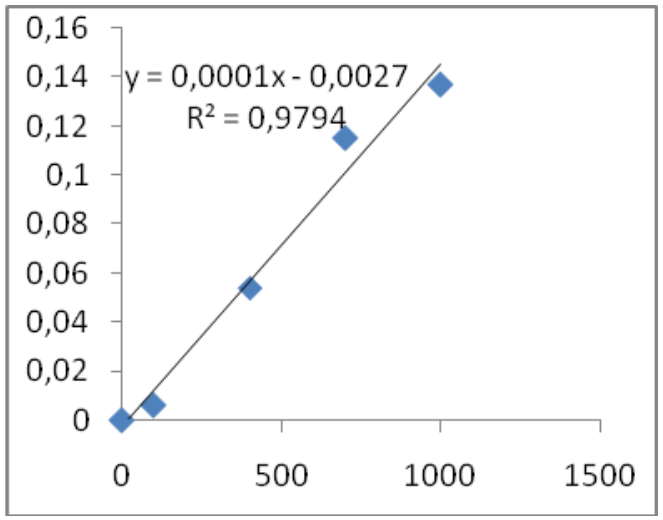

Gambar 7. Kurva Kalibrasi standar COD

Tabel 2.Kandungan COD pada Penelitian

\begin{tabular}{|c|c|c|}
\hline No & Keterangan & $\begin{array}{c}\text { Kandungan } \\
\text { COD }\end{array}$ \\
\hline 1 & Sampel Awal & $2270 \mathrm{ppm}$ \\
\hline 2 & $\begin{array}{c}\text { Hasil Elektrolisis 5 } \\
\text { jam 15 volt }\end{array}$ & $617 \mathrm{ppm}$ \\
\hline
\end{tabular}

Dari data diatas didapatkan bahwa konsentrasi COD dari sampel limbah laundri yaitu sebesar 2270 ppm. Dan hasil konsentrasi dari sampel hasil elektrolisis 20 volt selama 5 jam yaitu sebesar 617 ppm. Dengan didapatkannya data tersebut maka dapat dikatakan bahwa kadar COD dalam penelitian ini turun dengan sangat drastis dan mengalami penurunan kadar COD yang cukup besar. Sehingga dalam penelitian ini juga didapatkan bahwa kadar oksigennya dapat turun dengan melakukan elektrolisis dengan potensial dan waktu yang optimum 
yaitu dengan potensial 20 volt dengan waktu 5 jam.

\section{KESIMPULAN}

1. Hasil yang didapatkan dari penelitian maka dapat diambil kesimpulan bahwa metode elektrolisis dengan menggunakan karbon dapat digunakan untuk mendegradasi limbah laundri dengan cukup baik.

2. Presentase degradasi dari limbah laundri yang diapatkan dengan hasil yang baik yaitu sebesar $50,98 \%$ pada saat elektrolisis dengan menggunakan Tegangan 20 volt dan waktu selama 5 jam.
3. Kadar COD dalam penelitian ini juga mengalami penurunan yaitu ketika sampel masih belum di elektrolisis adalah 2270 ppm dan setelah dielektrolisis kini menjadi 617 ppm. Dengan persentase penurunan yaitu 72,819 \%.

\section{UCAPAN TERIMAKASIH}

Penulis mengucapkan terima kasih kepada bapak Riyanto, Ph.D. dan bapak Tatang Shabur Julianto, S.Si., M.Si. yang telah memberikan arahan untuk penelitian ini.

\section{DAFTAR PUSTAKA}

Aygun, A., dan Yilmaz,T., 2010, Improvement of Coagulation-Flocculation Process for Treatment of Detergent Wastewaters Using Coagulant Aids, InternationalJournal of Chemical and Environmental Engineering, Volume 1, No.2, 97-101

Anggi, R,. 2013. Pengolahan Limbah laundri dengan Biosand filter dan karbon aktif. Teknik Sipil Untan, vol 13.

Catur, N.,2012, Degradasi Senyawa Linear Alkil Sulfonat dengan Fotokatalis $\mathrm{TiO}_{2}$. UI Press, Jakarta.

Ciabatti,et al., 2010. Demonstration of a treatment system for purification and reuse of laundry wastewater,Desalination 245:451-459,USA.

Crittenden,B dan W.J Thomas., 1998. Adsorption Technology and Design,Elseviere Science and Technology Book,Amsterdam.

Effendi, H.,2003, TelaahKualitas Air. Yogyakarta, Kunisius.

Fardiaz, S.,1992. Polusi Air dan Udara. Penerbit Kanisius, Jakarta.

Fitria, A., 2012, Analisis Limbah Cair dengan Elektrokoagulasi, Teknik Kimia UI, Vol 1, 12-13.

Ginting,P., 2007. Sistem Pengelolaan Lingkungandan Limbah Industri. Bandung,YramaWidya. 
Holt, P., 2002. Electrocoagulation :Undervelling and Synthesising the Mechanisms Behind a Water Treatment Process [tesis]. Sydney : Doctor of Philosophi in Chemical Enginee-ring, University of Sydney.

Kok, T., 1997, "Spektrofotometri UV-Vis Aplikasi Kuantitatif “, mipa ubaya.

Kubare, M. danHaarhoff, J. 2010."Rational Design Of Domestic Biosand Filters". Journal Of Water Supply: Research And Technology.

Marsono, B. D. 1999. "Teknik Pengolahan Air Limbah Secara Biologis". Surabaya, ITS press.

Metcalf dan Eddy. 2003. Wastewater Engineering Treatment and Reuse. 4th.USA.

Pratama, M. A. 2008. Penurunan Kadar Detergen Pada Limbah Cair Laundry Dengan Menggunakan Reaktor Biosand Filter Yang Diikuti Reaktor Activated Carbon. Yogyakarta, Universitas Islam Indonesia.

Priyanto, B., 2006. Uji Toksisitas Dua Jenis Surfaktan dan Detergen Komersial menggunakan Metode Pengahmbatan Pertumbuhan Lemma sp. Vol $3 \mathrm{Hal}$ 251-257.Jakarta

Rahayu, T., 2004, Karakteristik Air Sumur Dangkal di Wilayah Kartasura dan Upaya Penjernihannya, Jurnal Mipa, Vol. 14 (1).

Retno,S., 2008.Kajian proses Elektrokuagulasi untuk Pengolahan Limbah Cair,Seminar Nasional IV SDM Teknologi Nuklir.Yogyakarta.

Riyanto., 2013, Elektrokimia dan Aplikasinya. Universitas Islam Indonesia, Jogjakarta

Rochman, F., 2009. Pembuatan IPAL Mini untuk Limbah Detergen Domestik. Med Eksakta. Jakarta

Ryadi, S.,1984. Seri Lingkungan (Pencemaran): Pencemaran Air, Dasar-dasar dan Pokok Penanggulangannya.

Penerbit Karya Anda., Surabaya

Sihombing, J. B. F, 2007, penggunaan Media Filtran Dalam Upaya Mengurangi Beban Cemaran Limbah Cair Industri Kecil Tapioka, DepartemenTeknologi Industri Pertanian Fakultas Teknologi Pertanian IPB, Bogor.

Smulders, E.,2002, Laundry Detergents, Wiley-VCH Verlag GmbH, Weinheim, Germany.

Snyder,C.H.,1995.The Extraordinary Chemistry of Ordinary Things,Kanada.

Sugiharto., 2008. Dasar-DasarPengelolaan Air Limbah.Jakarta, UI-Press.

Turk,S.S,I.Petrinic,M.Simonic.,2005, Laundry wastewater treatment usingcoagulation and membrane filtration, Resources, Conservation \& Recycling,44, 185-196

Winardi., 2001, Studi Kinetika Penyisihan Organik pada Sequencing Batch Reactor Aerob dengan Parameter Rasio Waktu Pengisian Terhadap Waktu Reaksi, ITB, Bandung. 